\title{
MENINGKATKAN HASIL BELAJAR PRAKTEK REKORDER DENGAN MODEL COOPERATIVE LEARNING DI KELAS VIII SMP
}

\author{
Desniwati
}

SMPN 2 Palupuh Kab. Agam

\begin{abstract}
Abstrak
Penelitian ini dilatar belakangi oleh keinginan untuk memperbaiki proses pembelajaran yang telah dilakukan dengan tujuan menjelaskan hasil belajar peserta didik dengan menerapkan model cooperativelearning pada mata pelajaran Seni Budaya (seni musik). Metodologi penelitian yang digunakan adalah penelitian tindakan kelas (PTK). Pengumpulan data dilakukan dengan observasi, wawancara dan studi pustaka. PTK ini terdiri atas 2 siklus. Hasil penelitian menunjukkan bahwa pembelajaran dengan model Cooperative Learningpada materi praktek rekorder pada musik ansabel dapat meningkatkan keterampilan siswa bermain musik. Saran yang dapat diberikan berkaitan dengan penelitian ini adalah guru harus jeli dalam memilih anggota kelompok dan guru harus menjadi motivator bagi siswa dalam mempelajari penggunaan rekorder pada music ansambel.
\end{abstract}

Kata kunci: hasil belajar, praktek recorder, model cooperative learning.

c. (1) This is an open access article distributed under the Creative Commons Attribution License, which permits unrestricted use, distribution, and reproduction in any medium, provided the original work is properly cited. (C2017 by author and IICET.

\section{PENDAHULUAN}

Pendidikan cara untuk mencerdaskan kehidupan bangsa karena pendidikan dapat meningkatkan harkat dan martabat bangsa (Indonesia, P. R. 2003).Dalam UU No. 20 tahun 2003 tentang Sistem Pendidikan Nasional disebutkan "Pendidikan Nasional bertujuan untuk mengembangkan potensi diri siswa untuk memiliki kekuatan spiritual keagamaan, pengendalian diri, kepribadian, kecerdasan, akhlak mulia, serta keterampilan yang diperlukan dirinya, masyarakat, bangsa dan negara. 
Sekolah adalah salah satu pendidikan formal(Rismayanthi, C. 2011; Wibowo, N. 2016), yang pengelolaannya di lakukan oleh tenaga pendidik yang disebut guru (Iskandar, U. 2013; Ulya, A. 2010). Bentuk pengelolaan tersebut dilakukan dengan melaksanakan proses pembelajaran yang interaktif, terorganisasi dan sistematis, yang bertujuan agar peserta didik dapat menguasai, memiliki, ranah pengetahuaan, sikap dan keterampilan serta applikasi motorik secara seimbang.Sekolah mempersiapkan peserta didik dengan berbagai keterampilan(Purnamasari, Y. 2013; Rahma, A. N. 2012; Syafitri, W. 2011; Wulandari, M. W., Liliasari, M., \& Supriyanti, M. T. 2011), seperti penguasaan bidang studi, menganalilsis dan mengambil keputusan secara rasional, berkomunikasitulis dan lisan dalambahasa asing, bekerjasama serta keterampilan rasionaltertentu (Mubasir, 2015).

Mata pelajaran yang di pelajari di Sekolah Menengah Pertama (SMP), salah satunya adalah Seni Budaya (Purnaningtyas, A., \& Suharto, S. 2010; Kinesti, R. D. A. 2013). Muatan seni budaya di amanatkan dalam peraturan Pemerintah Republik Indonesia No.19 tahun2005 tentang "standar nasional pendidikan tidak hanya terdapat dalam satu mata pelajaran, karena budaya itu sendiri meliputi segala aspek kehidupan". Dalam mata pelajaran seni budaya, aspek budaya tidak di bahas secara tersendiri tetapi terintegrasi dengan seni (Suharto, S. 2012; Purnaningtyas, A., \& Suharto, S. 2010; Aesijah, S. 2009).Karena itu mata pelajaran seni budaya pada dasarnya merupakan pendidikan seni berbasis budaya. Seperti yang tercantum dalam buku panduan kurikulum standar kompetensi untuk mata pelajaran seni, yang berbunyi:

"Mata pelajaran seni memiliki fungsi dan tujuan menumbuh kembangkan sikap toleransi, demokrasi, beradab, serta mampu hidup rukun dalam masyarakat yang majemuk, mengembangkan kemampuan imajinatif intelektual ekspresi melalui seni, mengembangkan kepekaan rasa, keterampilan, serta mampu menciptakan teknologi dalam berkreasi dan dalam memamerkan dan mempergelarkan karya seni (Depdiknas, 2003 : 2-3)"

Pembelajaran di SMP N 2 Palupuh dilaksanakan dengan berpedoman pada kurikulum KTSP yang telah ditetapkan oleh Dinas Pendidikan.Tujuan pembelajaran seni budaya dalam kurikulum KTSP (Yusuf, A. 2007; Utomo, U. 2010) adalah membangun landasan bagi perkembangan potensi peserta didik agar menjadi manusia yang: (a) beriman dan bertaqwa kepada Tuhan Yang Maha Esa, berakhlak mulia dan berkepribadian luhur; (b) berilmu, cakap, kritis, kreatif dan inovatif; (c) sehat, mandiri, dan percaya diri; dan (d) toleran, peka sosial, demokratis dan bertanggungjawab.Selain itu, guru juga melaksanakan pembelajaran berpedoman pada tujuan visi serta misi sekolah SMP N 2 Palupuh yang mengarah pada tujuan pendidikan Nasional, yang telah ditetapkan pemerintah Republik Indonesia.

Pendidikan seni budaya meliputi: seni tari, seni teater, seni rupa dan seni musik. Tugas guru dalam pembelajaran, yaitu menciptakan suasana belajar yang efektif dan kreatif berdasarkan standar kompentensi dasar.Secara garis besar kompentensi dasar dari masing-masing cabang seni itu dibagi dua, yakni mengapresiasikan karya seni bersifat teoritis dan mengekspresikannya dalam bentuk pratikum(Faisal, 2013).

Salah satu cabang seni yang diajarkan adalah seni musik.Standar Kompetensi (SK) untuk kelas VIII Semester 2 adalah mengekspresikan diri melalui karya seni musik, dan kompetensi dasar (KD.2).Menyajikan karya seni musik tradisional Nusantara secara perorangan dan kelompok dikelas atau sekolah.Tujuan pembelajaran menyajikan hasil aransmen lagu nusantara melalui ansambel musik.

Ansambel adalah bentuk permainan musik secara bersama, terdiri ansambel sejenis dan ansambel campuran. Dalam pembelajaran ini peneliti melaksanakan ansambel sejenis yaitu menggunakan alat musik rekorder.Berdasarkan hasilujian mid semester 2 di SMP N 2 Palupuh khususnya kelas VIII, diketahui hasil belajar peserta didik dalam pembelajaran musik masih rendah dibandingkan dengan kelas yang lainnya yang sudah mencapai nilai di atas KKM. Hal ini dibuktikan dengan hasil belajar praktek ansanmbel (praktek rekorder) yang diperoleh peserta didik kelas VIII rata-rata 70,54 sedangkan Kriteria Ketuntasan Minimal 75. Tingkat pemahaman peserta didik dalam menguasai materi music ansambel masih rendah.

Hasil pengamatan dan wawancara dengan siswa diketahui bahwa hal ini terjadi karena mereka menggangap pembelajaran seni musik membosankan, sarana dan prasarana kurang memadai, dan metode yang digunakan kurang tepat.Sementara tuntutan untuk mencapai nilai tinggi harus dilaksanakan. Perubahan tuntutan belajar dari masa sebelumnya juga menyebabkan munculnya gejalastress. Kondisi iniantara lain disebabkan oleh tuntutan yang tinggi terhadap prestasi siswa (Taufik \& Ifdil, 2013). Sehingga munculnya sikap egois peserta didik pandai 
yang merasa tinggi hati dan enggan berbagi kecakapan dengan temannya yang belum menguasai alat musik secara baik.Rendahnya motivasi berlatih musik sebagian pesertadidik terutama; 1.Penguasaan teknik penjarian rekorder, 2.Peniupan rekorder tidak sesuai dengan teknik yang diinginkan, 3.Kurang memahami membaca notasi.Ini semua disebabkan karena kurangnya perhatian,dan keaktifan peserta didik berlatih sendiri dan terbatasnya bimbingan yang diberikan. Keterbatasan daya pemantauan guru kepada peserta didik dalam pengusaan musik di luar sekolah juga berdampak lambatnya mengasah skill peserta didik. Sehingga pembelajaran praktek rekorder belum mencapai hasil yang diharapkan.Hasil ulanganharian dapat di lihat dibawah ini.

Tabel 1. Nilai hasil ulangan harian Seni Budaya

\begin{tabular}{cccccc}
\hline No & Kelas & KKM & Hasil Belajar & Tuntas & Tidak Tuntas \\
\hline $\mathbf{1}$ & VII a & 75 & 75 & 17 & 4 \\
$\mathbf{2}$ & VII b & 75 & 76 & 15 & 6 \\
$\mathbf{3}$ & VIII & 75 & 70,54 & 12 & 25 \\
$\mathbf{4}$ & IX a & 75 & 79,82 & 20 & 3 \\
$\mathbf{5}$ & IX b & 75 & 78,65 & 22 & 1 \\
\hline
\end{tabular}

Berdasarkan tabel di atas dapat di lihat dari lima kelas, kelas yang bermasalah adalah kelas delapan dengan rata rata 70,54

Meningkatkan kualitas pembelajaran seni budaya yang mencakup tiga ranah kompetensi, salah satunya dengan menggunakan model pembelajaran kooperatif. Pembelajaran kooperatif menurut Sanjaya(2006) akan efektif digunakan apabila: (1) guru ingin menekankan kerjasama di samping usaha secara individual, (2) guru ingin menghendaki pemerolehan hasil dalam belajar, (3) guru ingin menanamkan tutor sebaya atau belajar melalui teman sendiri, (4) guru menghendaki adanya pemerataan partisipasi aktif peserta didik,(5) guru menghendaki kemampuan peserta didik dalam memecahkan berbagai permasalahan. Dengan demikian diharapkan dengan menggunakan model pembelajaran cooperative learning dapat meningkatkan hasil belajar Praktek Rekorder di Kelas VIII SMPN 2 Palupuh.

\section{METODE}

Jenis penelitian ini adalah Penelitian Tindakan Kelas (PTK) yang bertujuan untuk meningkatkan kreatifitas belajar praktek lagu nusantara dengan rekorder.Penelitian ini dilakukan di SMPN 2 Palupuhpada kelas VIII pada semester 2 tahun 2015-2016.Jumlah peserta didik 37 orang yang terdiri dari laki-laki 12 orang dan perempuan 25 orang.

Penelitian ini dilaksanakan sebanyakdua siklus.Setiap siklus terdiri dari dua kali pertemuan.Pada siklus I Materi yang diajarkan adalah lagu Nusantara (Burung Kakak Tua). Guru membagi peserta didik menjadi 9 kelompok secara heterogen. Setiap kelompok terdiri dari 4 orang.Data dianalisis secara deskriptif.Langkah penelitian dijelaskan berikut ini.

\section{Siklus I}

1) Perencanaan
a. Mempersiapkan segala kebutuhan baik perangkat pembelajaran(RPP).
b. Mempersiapkan alat atau media pembelajaran.
c. Guru akan membuat laporan observasi kemandirian peserta didik.
d. Guru akan menyiapkan blangko penilaian praktek musik.
e. Peserta didik akan menyanyikan lagu dengan musik rekorder.

2) Pelaksanaan

Langkah - langkah pelaksanaan adalah sebagai berikut (2x pertemuan).

a. Guru menyampaikan/memgkomunikasikan tujuan pembelajaran kepada peserta didik dan memotivasi untuk belajar.

b. Guru menyajikan informasi kepada peserta didik dengan model yang dapat membuat peserta didik tertarik belajar. 
c. Guru membagi peserta didik atas 9 kelompok secara heterogen tiap kelompok terdiri atas 4 orang, cara pembentukan kelompok di serahkan kepada peserta didik.

d. Guru menyuruh peserta didik berlatih mainkan musik rekorder secara kelompok sesuai dengan kelompok yang telah dibentuk, guru membimbing kelompok.

e. Guru menyuruh peserta didik menyanyikan lagu nusantara (burung kakak tua) dengan rekorder sesuai dengan tekniknya.

f. Guru mengambil nilai persiapan proses, dan mengambil nilai praktek rekorder.

g. Guru memberikan penghargaan hasil belajar.

3) Pengamatan

Pada pengamatan ini dilkukan pemantauan atau pengamatan yang berguna untuk mengetahui apakah tindakan yang dilakukan mencapai hasil yang diharapkan:

a. Peserta didik akan mainkan musik rekorder sesuai tekniknya.

b. Peserta didik akan menjelaskankembali teknik peniupan rekorder.

c. Peserta didik akan mengungkapkan kemampuaannya memainkan musik rekorder, dengan lagu Burung 4) Refleksi.

Kakak Tua secara berkelompok.

Berdasarkan pengamatan atau observasi tentang kemandirian peserta didik dan refleksi ini tergambar hasil yang dicapai. Kekurangan yang ditemukan akan dibahas pada sikklus berikutnya.

\section{Siklus II}

Perencanaan siklus kedua ini berdasarkan refleksi pada siklus pertama. Untuk siklus kedua ini, masih dirasa perlu beberapa perbaikan karena hasil belajar pada siklus pertama belum mencapai target yang diinginkan, yaitu dengan tidak mengubah siklus pertama.

1. Perencanan

a. Mempersiapkan segala kebutuhan, perangkat pembelajaran (RPP).

b. Mempersiapkan alat dan media pembelajaran.

c. Membuat lembar observasi.

d. Mempersiapkan penilaian proses.

e. Mempersiapkan penilaian hasil.

2. Pelaksanaan Tindakan

a. Sebelum masuk siklus kedua, guru memberikan reward atau penghargaan kepada peserta didik yang hasil prateknya bagus pada siklus pertama.

b. Pada siklus kedua ini peserta didik yang kreatif diberi kesempatan memotivasi peserta didik yang kurang kreatif. Dalam pelaksanaan kelompok masih terdiri atas 9 kelompok tiap kelompok terdiri atas 4 orang. Gurumemulai pelajaran dengan memberikan contoh peniupan rekorder.

c. Peserta didik mendengarkan atau memperhatikan dengan seksama.

d. Guru mengambil nilai proses.

e. Nilai proses tertinggi diberikan penghargaan berupa pujian atau dalam bentuk yang lain.

3. Pengamatan

Hal yang diamati dalam siklus kedua ini sama dengan yang dilakukan pada siklus pertama yaitu kemampuan dalam praktek instrumen rekorder.

4. Refleksi.

Melakukan kegiatan refleksi pertama yang dikumpulkan dari lembaran observasi diolah secara kualitatif. Dan refleksi kedua hasil yang dicapai dibandingkan dengan siklus pertama, apakah terjadi peningkatan kreatifitas peserta didik atau tidak.

\section{HASIL DAN PEMBAHASAN}

Prasiklus 
Pelaksanaan pembelajaran praktek musik (praktek rekorder) dikelas VIII di SMP N 2 Palupuh dilaksanakan dalam bentuk klasikal dan kelompok dengan menggunakan metode demontrasi , hasil belajar belum memuaskan dari 37 peserta didik yang tuntas hanya 9 orang ( 24,32) dan yang tidak tuntas 28 orang $(75,67)$, oleh karena itu agar hasil belajar peserta didik mencapai target yang diinginkan sesuai dengan kkm (75) perlu diadakan tindakan kelas dalam bentuk penelitian tindakan kelas (PTK).

\section{Siklus I}

\section{Pertemuan I}

\section{Perencanaan kegiatan}

Pada pembelajaran awal guru memfokuskan pembelajaran pada 1) mengkondisikan kelas (mencek kesiapan belajar peserta didik), 2) berdo'a, 3)absensi, 4) melakukan apersepsi mengenai materi yang dipelajari sebelumnya, menghubungkan dengan pelajaran yang dipelajari, 5) Menyampaikan Tujuan Pembelajaran ,6) membagi peserta didik dalam kelompok belajar. Pada kegiatan inti dimulai dengan tahap, 1) Menyampaikan tujuan dan memotivasi peserta didik. 2) Menyajikan informasi3)Mengorganisasikan kelompok belajar. 4) Membimbing kelompok belajar dan bekerja, 5) Evaluasi, 6) memberikan penghargaan.

\section{Pelaksanaan}

Pada pertemuan I pembelajaran menggunakan materi lagu Nusantara dari Maluku dengan judul Burung Kakak Tua, birama lagu 3/4,dasar nada c, tempo andante.Kegiatan awalguru melakukan apresiasi dengan berdoa, mengaji mengecek kesiapan belajar peserta didik serta memberikan motivasi nilai karakter, jujur, komunikatif, kecintaan, dan percaya diri.

Kegiatan inti, Eksplorasi dengan melakukan: - Guru meminta beberapa orang peserta didik untuk menampilkan lagu menggunakan rekorder sesuai dengankemampuannya.- Guru memberikan pengarahan dari hasil penampilan peserta didik.- Guru menyampaikan tujuan pembelajaran dan memotivasi peserta didik untuk belajar.Elaborasidenganmelakukan:-Guru menerangkan jenis musik rekorder, dan menerangkan teknik peniupan ,dan teknik penjarian.-Melatih membaca notasi prase/prase dan baris/ baris secara individu dan klasikal, dengan menggunakan rekorder. - Guru membentuk kelompok peserta didik atas Sembilan kelompok, setiap kelompok terdiri atas empat orang anggota, pemilihan angota diserahkan guru kepada peserta didik dibawah bimbingan guru. - Membimbing kelompok bekerja dan belajar guru mmengamati kerja kelompok peserta didik yang telah mulai melakukan diskusi praktek rekorder dan memberikan kesempatan bertanya bagi peserta didik yang belum memahami tugasnya. - Evaluasi Masing-masing kelompok menampilkan kedepan kelas hasil latihannya, kelompok lain mengamati dan memberikan tanggapan setelah diberikan guru waktu untuk memberikan tanggapan.Konfirmasi, dengan memberikan penghargaan. Guru memberikan pujian kepada peserta didik yang mampu membawakan lagu Burung kakak tua dengan baik dan meminta peserta didik lain tepuk tangan dengan tujuan agar yang telah berhasil bisa percaya diri dan yang belum mampu dapat lebih giat lagi.

Pada kegiatan penutup, guru memberikan penghargaan terhadap apa yang dilaksanakan peserta didik. Kemudian guru meminta kepada peserta didik untuk menyimpulkan pelajaran dan selanjutnya guru memberikan tugas rumah kepada semua peserta didik dan menyampaikan rencana untuk pertemuan minggu depan.

\section{Pengamatan}

Pada pertemuan pertama ini ada12 orang peserta didik yang tidak mempunyai alat musik sendiri untuk latihan di sekolah rekorder di pinjamkan, peserta didik hanya mengandalkan latihan di sekolah sehingga masih ada yang belum mampu melakukan tenik penjarian dengan benar.Hasil belajar pada siklus I pertemuan I belum belum mengambil hasil belajar secara tertulis, akan tetapi dari hasil pengamatan yang dilakukan oleh guru dan observerbelum semua peserta didik yang dapat melakukan teknik peniupan dan membaca notasi dengan benar.

\section{Refleksi}

Agar hasil belajar lebih baik, disarankan kepada peserta didik untuk disiplin latihan, dan jangan malu bertanya terhadap hal yang tidak dimengerti, usahakan memiliki instrumen rekorder.Pada kegiatan awal, guru sudah baik dalam menerangkan materi yang diberikan.Tapi peserta didik masih ada yang belum serius melakukan praktek musik rekorder, tidak mau disiplin latihan.Gambaran secara umum kemampuan bermain musik rekorder 
masih banyak yang kurang.Dari itu guru perlu memberikan arahan dan motivasi untuk memperbaiki kinerja peserta didik.

\section{Pertemuan II}

\section{Perencanaan kegiatan}

Pada pertemuan kedua ini Guru mengulas kembali cara membaca notasi yang benar, dan tenik penjarian yang tepat dalam peniupan rekorder.

\section{Pelaksanaan}

Padakegiatan awal/ pendahuluan, guru melaksanakan apresiasi yaitu dengan mencek kesiapan peserta didik untuk belajar, berdo'a dan mengaji.Memberikan motivasi, dengan memberikan kesempatan pada peserta didik untuk menampilkan hasil latihan praktek rekorder di depan kelas. Memberikan arahan pada peserta didik teknik peniupuan yang benar.Pada kegiatan inti pertemuaan guru melaksanakan tahap kegiatan:Eksplorasi dengan melakukan - Menyampaikan tujuan pembelajaran dan memotivasi peserta didik, dengan menampilkan hasil latihan ke depan. -Tanya jawab dengan masing-masing kelompok terhadap kesulitan yang dihadapinya. Elaborasi: - Untuk pemahaman peserta didik dalam menampilkan bentuk ansambel, mengorganisasikan peserta didik dalam bentuk kelompok, Membimbing kelompok bekerja dan belajar. Dalam hal ini guru meninjau kegiatan belajar peserta didik dengan menghampiri tiap kelompok dan memberikan bimbingan serta pengarahan bagi kelompok yang mengalami kesulitan.Konfirmasi: Memfasilitasi peserta didik untuk memperoleh pengalaman bermakna dalam mencapai kompetensi dasar, Peserta didik latihan dalam bentuk kelompok mempraktekan lagu Burung Kakak Tua dalam bentuk ansambel sejenis.Penutup, Pada kegiatan penutup guru mengadakan evaluasi hasil belajar praktek rekorder untuk pertemuan 1 dan 2 siklus I.Dari evaluasi yang diberikan pada setiap kelompok ternyata masih ada peserta didik yang belum mampu meniup rekorder dengan benar. Dari 37 orang jumlah peserta didik, yang berhasil baru hanya 15 ( 40,54\%) orang yang tuntas, $22(59,45 \%)$ tidak tuntas.

\section{Pengamatan}

Pada siklus 1 pertemuan 2 ini, masih ada yang merasa minder dengan teman,tidak mau berlatih sendiri dan juga dalam kerja kelompok belumterlihat perkembangan yang memuaskan. Hasil belajar siswa dapat dilihat pad atabel berikut ini.

Tabel 2.Rekapitulasi Nilai Praktek Rekorder Di Kelas VIII Siklus I

\begin{tabular}{|c|c|c|c|c|c|}
\hline No & Nama & Nilai aktivitas & Nilai praktek & Jumlah & Ket \\
\hline 1 & A M & 41 & 27 & 68 & TT \\
\hline 2 & A R & 46 & 37 & 81 & $\mathrm{~T}$ \\
\hline 3 & A I & 43 & 31 & 74 & $\mathrm{TT}$ \\
\hline 4 & Dw & 47 & 41 & 88 & $\mathrm{~T}$ \\
\hline 5 & D P S & 37 & 35 & 72 & TT \\
\hline 6 & DA & 38 & 29 & 67 & $\mathrm{TT}$ \\
\hline 7 & F RA. & 45 & 26 & 71 & TT \\
\hline 8 & GPJ & 39 & 27 & 66 & $\mathrm{TT}$ \\
\hline 9 & HD & 40 & 23 & 63 & $\mathrm{TT}$ \\
\hline 10 & $\mathrm{HM}$ & 43 & 33 & 76 & $\mathrm{~T}$ \\
\hline 11 & $\mathrm{HY}$ & 36 & 32 & 68 & $\mathrm{TT}$ \\
\hline 12 & $\mathrm{Fi}$ & 42 & 37 & 79 & $\mathrm{~T}$ \\
\hline 13 & IG & 44 & 36 & 80 & $\mathrm{~T}$ \\
\hline 14 & IR & 43 & 33 & 76 & $\mathrm{~T}$ \\
\hline 15 & IA & 37 & 31 & 68 & $\mathrm{TT}$ \\
\hline 16 & $\mathrm{HN}$ & 37 & 36 & 73 & $\mathrm{TT}$ \\
\hline 17 & KA & 45 & 35 & 80 & $\mathrm{~T}$ \\
\hline
\end{tabular}




\begin{tabular}{cccccc}
\hline $\mathbf{1 8}$ & M.F & & & & \\
$\mathbf{1 9}$ & MN & 36 & 40 & 76 & $\mathrm{~T}$ \\
$\mathbf{2 0}$ & MD & 43 & 36 & 79 & $\mathrm{~T}$ \\
$\mathbf{2 1}$ & MSA & 32 & 35 & 67 & $\mathrm{TT}$ \\
$\mathbf{2 2}$ & MN & 41 & 33 & 74 & $\mathrm{TT}$ \\
$\mathbf{2 3}$ & NP & 43 & 29 & 84 & $\mathrm{~T}$ \\
$\mathbf{2 4}$ & NK & 40 & 26 & 63 & $\mathrm{TT}$ \\
$\mathbf{2 5}$ & RH & 37 & 30 & 66 & $\mathrm{TT}$ \\
$\mathbf{2 6}$ & R R & 36 & 33 & 81 & $\mathrm{TT}$ \\
$\mathbf{2 7}$ & S E & 48 & 36 & 80 & $\mathrm{~T}$ \\
$\mathbf{2 8}$ & VC & 44 & 32 & 77 & $\mathrm{~T}$ \\
$\mathbf{2 9}$ & YF & 45 & 29 & 68 & $\mathrm{~T}$ \\
$\mathbf{3 0}$ & YL & 39 & 28 & 78 & $\mathrm{~T}$ \\
$\mathbf{3 1}$ & YA & 42 & 27 & 66 & $\mathrm{~T}$ \\
$\mathbf{3 2}$ & ZF & 38 & 30 & 70 & $\mathrm{TT}$ \\
$\mathbf{3 3}$ & IH & 43 & 36 & 77 & $\mathrm{TT}$ \\
$\mathbf{3 4}$ & LS & 28 & 35 & 70 & $\mathrm{~T}$ \\
$\mathbf{3 5}$ & AS & 41 & 33 & 70 & $\mathrm{TT}$ \\
$\mathbf{3 6}$ & DR & 35 & 33 & 68 & $\mathrm{TT}$ \\
$\mathbf{3 7}$ & DAP & 37 & & $\mathrm{TT}$ \\
& Jumlah/ rata-rata & 35 & & & \\
\hline
\end{tabular}

Ket $: \mathrm{T}=$ Tuntas $\mathrm{TT}=$ Tidak tuntas

Dari data di atas disimpulkan bahwa dengan jumlah 37 peserta didik, yang tuntas hanya 15 orang dan yang tidak tuntas 22 orang.

\section{Refleksi}

Pencapaian hasil ulangan harian I belum memuaskan maka diadakan tindakan untuk siklus II.

\section{Siklus II}

\section{Pertemuan I}

\section{Perencanaan Kegiatan}

Agar hasil belajar dapat maksimal perlu diadakan perbaikan untuk Siklus II.Pada siklus kedua ini peserta didik yang kreatif, berpotensi diberi kesempatan untuk memotivasi peserta didik yang kurang aktif. Dalam hal ini teknik yang dilakukan adalah dengan memilih peserta didik didik yang pintar untuk membantu temannya dalam kelompok.

\section{Pelaksanaan}

Pada kegiatan awal guru melaksanakan apresiasi, berdo'a, dan meninjau kesiapan belajar peserta didik, setelah itu tanya jawab tentang materi dengan menanyakan apakah sudah trampil memainkan lagu burung kakak tua dengan rekorder.Guru memberikan pengarahan pada peserta didik untuk melakukan praktek relorder dengan benar secara individu dan kelompok. Kegiatan inti dimulai dengan kegiatanEksplorasi: - Guru Tanya jawab dengan kelompok dari hasil belajar sikklus I. - Guru menempatkan peserta didik yang kreatif, dan berkompeten untuk membantu teman dalam kelompok.Elaborasidilakukan dengan - Mengulangi kembali materi yang tidak dikuasai peserta didik. - Guru memberikan kesempatan berlatih kepada setiap kelompok yang dipandu dengan teman yang telah dipilih oleh guru dengan waktu 50 menit. - Guru mengamati proses kerja kelompok dan membimbing anggota kelompok yang terkendala latihannya. - Pemandu kelompok melatih temannya yang belum paham teknik penjarian.Konfirmasi denganMemberikan umpan balik positif dan penguatan hasil belajar.Penutup, Pada kegiatan ini, 10 menit terakhir guru memberikan kesempatan pada kelompok terbaik menampilkan hasil latihan didepan kelas. Gurumemberikan penghargaan dan motivasi kepada setiap kelompok atas kinerja yang dilakukan, memberikan tugas kepada peserta didik untuk latihan di rumah, untuk persiapan ujian minggu pertemuan berikutnya. 


\section{Pengamatan}

Selama proses belajar berlangsung terlihat beberapa perubahan: 1) Peserta didik yang enggan bertanya, dan malu-malu,sudah mau bertanya dan juga sudah mau berbagi dengan temannya, 2) yang sering tidak bawa alat musik sudah membawa semuanya. Pada aspek peserta didik, mereka sudah menyadari arti penting kerjasama dalam suatu kelompok, sehingga dapat memahami kiat berkelompok yang baik antar peserta didik dan teman yang memandu kelompok.Hasil belajar siklus II pertemuan I ini belum ada, secara umum gambaran proses belajarnya sudah membaik.

\section{Refleksi}

Kegiatan pembelajaran umumnya sudah berlangsung baik, namun ada beberapahal yang perlu dibenahi, seperti kelengkapan instrument rekorder, kerjasama dalam kelompok, dan sikap saling menghargai antara sesama, dan lebih meningkatkan disiplin dalam latihan.

\section{Pertemuan II \\ Perencanaan}

Pada siklus II pertemuan II ini direncanakan untuk pengambilan nilai ujian praktek rekorder peserta didik kelas VIII SMPN 2 palupuh, sesuai dengan yang sudah direncanakan.

\section{Pelaksanaan}

Pelaksanan pembelajaran siklus II pertemuan II melakukan ujian unjuk kerja/ praktek kemampuan peserta didik dalam menampilkan lagu nusantara yang berjudul Burung kakak Tuadengan rekorder dalam bentuk ansambel.Kegiatan awal, Seperti biasa guru memasuki kelas dengan mengucapkan salam, peserta didik menjawab salam. Kegiatan inti dengan melakukan: -Mencek kesiapan belajar peserta didik, berdo'a,absensi.Motivasi,Menyampaikan tujuan pembelajaran, dan tanyajawab tentang kendala dalam melaksanakan latihan menggunakan rekorder.Selanjutnya meminta peserta didik menampilkan hasil latihan praktek rekorder.- Memberikan penghargaan terhadap kelompok yang tampil dan kelompok yang belum maksimal latihanya.Eksplorasi: - Memfasilitasi peserta didik berkelompok untuk berlatih rekorder. - mengamati proses kerja kelompok.Elaborasi: - Membimbing peserta didik latihan dengan pendamping kelompok untuk satu jam pelajaran. Konfirmasi : -melakukan ujian praktek menampilkan lagu nusantara dengan menggunakan rekorder.

\section{Penutup}

Melaksanakan evaluasi, peserta didik menampilkan lagu Burung Kakak Tua dalam bentuk ansambel sejenis. Memberikan reward untuk semua anggota kelompok.

\section{Pengamatan}

Setelah melaksanakan tes unjuk kerja didapat hasil belajar peserta didik meningkat dari hasil siklus I yaitu nilainya rata-rata diatas standar ketuntasan minimal dengan rata- rata 79,86.

Tabel 3.Rekapitulasi Nilai Praktek Rekorder Di Kelas VIII Siklus II

\begin{tabular}{|c|c|c|c|c|c|}
\hline No & Nama & Nilai Aktivitas & Nilai Praktek & Jumlah & Ket \\
\hline 1 & $\mathrm{AM}$ & 43 & 43 & 86 & $\mathrm{~T}$ \\
\hline 2 & $\mathrm{AR}$ & 46 & 46 & 92 & $\mathrm{~T}$ \\
\hline 3 & AI & 40 & 37 & 77 & $\mathrm{~T}$ \\
\hline 4 & DW & 47 & 47 & 94 & $\mathrm{~T}$ \\
\hline 5 & DPS & 41 & 41 & 82 & $\mathrm{~T}$ \\
\hline 6 & DA & 41 & 39 & 80 & $\mathrm{~T}$ \\
\hline 7 & FRA & 32 & 44 & 80 & $\mathrm{~T}$ \\
\hline 8 & GPJ & 31 & 42 & 75 & $\mathrm{~T}$ \\
\hline 9 & HS & 39 & 39 & 78 & $\mathrm{~T}$ \\
\hline 10 & $\mathrm{HM}$ & 40 & 40 & 80 & $\mathrm{~T}$ \\
\hline 11 & HY & 36 & 34 & 70 & TT \\
\hline
\end{tabular}




\begin{tabular}{cllllc}
\hline $\mathbf{1 2}$ & FK & 40 & 39 & 79 & $\mathrm{~T}$ \\
$\mathbf{1 3}$ & IG & 38 & 34 & 75 & $\mathrm{~T}$ \\
$\mathbf{1 4}$ & IR & 41 & 37 & 78 & $\mathrm{~T}$ \\
$\mathbf{1 5}$ & IA & 39 & 30 & 69 & $\mathrm{TT}$ \\
$\mathbf{1 6}$ & HN & 37 & 38 & 76 & $\mathrm{~T}$ \\
$\mathbf{1 7}$ & K & 42 & 48 & 80 & $\mathrm{~T}$ \\
$\mathbf{1 8}$ & M. F & 42 & 32 & 86 & $\mathrm{~T}$ \\
$\mathbf{1 9}$ & MN & 43 & 35 & 75 & $\mathrm{~T}$ \\
$\mathbf{2 0}$ & MD & 37 & 37 & 72 & $\mathrm{TT}$ \\
$\mathbf{2 1}$ & MSA & 40 & 37 & 87 & $\mathrm{~T}$ \\
$\mathbf{2 2}$ & MN & 45 & 41 & $\mathrm{~T}$ \\
$\mathbf{2 3}$ & NP & 40 & 35 & 72 & $\mathrm{~T}$ \\
$\mathbf{2 4}$ & NK & 37 & 36 & 83 & $\mathrm{TT}$ \\
$\mathbf{2 5}$ & RHF & 47 & 93 & $\mathrm{~T}$ \\
$\mathbf{2 6}$ & RR & 47 & 34 & 80 & $\mathrm{~T}$ \\
$\mathbf{2 7}$ & SE & 46 & 40 & 80 & $\mathrm{~T}$ \\
$\mathbf{2 8}$ & VC & 40 & 36 & 82 & $\mathrm{~T}$ \\
$\mathbf{2 9}$ & Y F & 45 & 40 & 80 & $\mathrm{~T}$ \\
$\mathbf{3 0}$ & YL & 40 & 40 & 80 & $\mathrm{~T}$ \\
$\mathbf{3 1}$ & YA & 40 & 42 & 75 & $\mathrm{~T}$ \\
$\mathbf{3 2}$ & ZF & 38 & 37 & 82 & $\mathrm{~T}$ \\
$\mathbf{3 3}$ & Ih & 33 & 40 & 80 & $\mathrm{~T}$ \\
$\mathbf{3 4}$ & LS & 45 & 44 & 88 & $\mathrm{~T}$ \\
$\mathbf{3 5}$ & AS & 40 & 35 & 76 & $\mathrm{~T}$ \\
$\mathbf{3 6}$ & DR & 44 & & \\
$\mathbf{3 7}$ & DAP & 41 & $\mathbf{2 9 5 5 / 7 9 , 8 6}$ & \\
Jumlah/rata-rata & & & & \\
\hline
\end{tabular}

Ket : $\mathrm{T}=$ Tuntas

$\mathrm{TT}=$ Tidak tuntas

\section{Refleksi}

Pembelajaran dengan menggunakan model Cooperative Learningdapat membantu siswa memiliki keterampilan menggunakan recorder dalam memainkan nada.Hasil perbandingan persentase penilaian sebelum dan sesudah dilaksanakan penelitian sebagai berikut.

Tabel 4.

Persetase Penilaian Sesudah Dilaksanakan PTK

\begin{tabular}{llcccc}
\hline No & & Nilai & Sebelum PTK & \multicolumn{2}{c}{ Setelah PTK } \\
\cline { 3 - 5 } & & & Siklus I & \multicolumn{2}{c}{ Siklus II } \\
& & Jlh siswa $\%$ & - & $3(8,10)$ \\
$\mathbf{1}$ & Sangat baik & Baik & $1(5,40)$ & $7(18,91)$ & $19(51,35)$ \\
$\mathbf{3}$ & Sedang & $20(54,05)$ & $16(43,24)$ & $14(37,83)$ \\
$\mathbf{4}$ & Cukup & $13(35,13)$ & $13(35,13)$ & $1(2,70)$ \\
$\mathbf{5}$ & Kurang & $1(2,70)$ & $1(2,70)$ & - \\
\hline
\end{tabular}

Perbandingan hasil belajar keterampilan menggunakan recorder pada pra siklus, siklus I dan II diketahui bahwa sudah banyak siswa dapat menggunakan recorder dengan baik. Tabel lengkapnya dapat dilihat pada grafik berikut ini. 


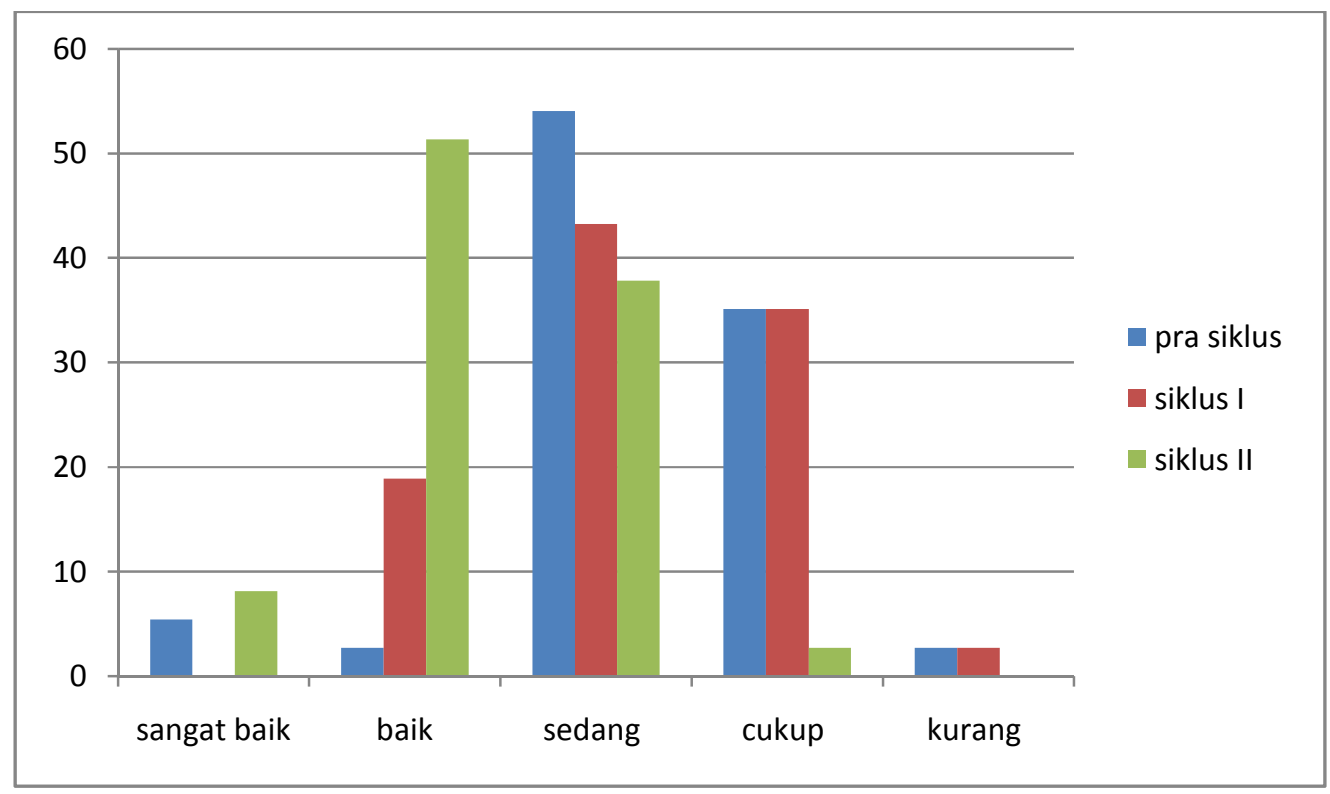

\section{Grafik 1. Hasil Belajar Praktek Rekorder Di Kelas VIII SMP N 2 Palupuh}

Data yang dijelaskan di atas menunjukkan bahwa pembelajaranmenggunakan model Cooperative Learning dapat meningkatkan hasil belajar keterampilann menggunakan recorder. Hal ini terjadi karena peserta didik dapat belajar dengan temannya dalam kelompok. Belajar secara berkelompok ini tidak hanya di dalam jam pelajaran tetapi dilanjutkan diluar jam pelajaran. Hal ini mampu meningkatkan motivasi belajar peserta didik.Pada akhirnya, dengan meningkatnya motivasi belajar peserta didik, hasil belajar mereka pun meningkat.

\section{Pembahasan}

Hasil penelitian yang telah dilaksanakan pada siklus I tentang aktivitas peserta didik yang diamati mendengar, bertanya, memperhatikan, diskusi dan tugas, tetapi masih ada peserta didik yang malu bertanya dan tidak membawa alat music (rekorder). Usaha yang dilakukan guru adalah menggunakan model Cooperative Learning. Peserta didik yang awalnya belum dapat bermain recorder dengan baik menjadi bisa memainkan recorder, tetapi belum semua peserta didik mampu meniup dan membaca notasi dengan benar.

Pada siklus II terlihat ada beberapa peserta didik yang memiliki kompetensi bagus dalam memainkan rekorder, maka diberi kesempatan untuk membantu teman-temannya dalam melakukan latihan praktek Ansambel lagu burung kakak Tua berkelompok. Melibatkan teman sebagai tutor dalam mempelajari recorder membuat siswa tidak malu untuk banyak bertanya. Pada masa-masa SMP (remaja) ini siswa lebih terbuka dan lebih banyak bersama temannya.Sehingga berlatih memainkan recorder bisa dilakukan di sekolah dan di luar sekolah.Hasil belajar siklus ke II menunjukkan perkembangan dari 37 peserta didik yang tuntas 33 orang dengan rata-rata kelas 79,86. Jadi dengan penerapan model Cooperative learning target yang diinginkan tercapai.

\section{SIMPULAN DAN SARAN}

Berdasarkan hasil penelitian dan pembahasan, kesimpulan yang dapat diambil adalah menggunakan model pembelajaran cooperative learning dapat meningkatkan hasil belajar peserta didik dalam pembelajaran seni music (praktekrekorder) di SMPN 2 Palupuh.

Saran yang dapat diberikan sehubungan dengan penerapan model pembelajaran cooperative learning dalam meningkatkan hasil belajar seni musik (praktekrekorder)sebagai berikut :

a. Guru harus jeli membuat kelompok, dengan menggabungkan siswa yang mampu dan mau membimbing temannya dalam bermain musik rekorder. 
b. Guru harus menjadi motivator bagi siswa dalam bermain music rekorder.

c. Pihak sekolah bersama Dinas Pendidikan hendaknya dapat meningkatkan dukungan terhadap pelaksanaan pembelajaran di sekolah terutama masalah ketersediaan alat-alat pembelajaran.

\section{DAFTAR RUJUKAN}

Dyah Purwani Setianingsih Dkk. 2000. Kerajinan Tangan Kesenian. Erlangga.

Harry Sulastianto, dkk. 2008. Seni Budaya: Grafindo Media Pratama.

Indonesia, P. R. (2003). Undang-undang Republik Indonesia nomor 20 tahun 2003 tentang sistem pendidikan nasional.

Iwayan Sadia, 2014. Model-model pembelajaran Sains Kunstruktivistik: Graha Ilmu.

Mubasir, A. (2015). Konsep Belajar Dan Pembelajaran. Retrieved from https://www.kompasiana.com/am-19/apaitu-konsep-belajar-dan pembelajaran_550d8ec9a333116e1c2e3c68

Faisal, M. (2013). Pengertian Belajar \& Pengertian Pembelajaran. Retrieved from http://ichaledutech.blogspot.co.id/2013/03/pengertian-belajar-pengertian.html

Motdjiono dan J.J Hasibuan. Proses Belajar Mengajar.

Taufik, T., \& Ifdil, I. (2013). Kondisi Stres Akademik Siswa SMA Negeri di Kota Padang. Jurnal Konseling dan Pendidikan, 1(2), 143-150. 